\title{
Adipofascial Turnover Forearm Flap for a Large Defect in Hand after Squamous Cell Tumor Extirpation. A Case Report
}

\author{
Miot Boncy D, MD* \\ Orthopedic and Hand Surgeon, Centro Médico Docente Los Altos, Av El Lago, Municipio Carrizal I203, Miranda, Venezuela \\ "Corresponding author \\ Miot Boncy, MD \\ Orthopedic and Hand Surgeon, Centro Médico Docente Los Altos, Av El Lago, Municipio Carrizal I203, Miranda, Venezuela; Tel. +58424-I560993; \\ E-mail:davemiot@gmail.com
}

\section{Article information}

Received: June 30 $0^{\text {th }}, 2021$; Revised: July 22 ${ }^{\text {nd }}$, 2021; Accepted: August $2^{\text {nd }}, 2021$; Published: August $9^{\text {th }}, 202$ I

\section{Cite this article}

Miot Boncy D. Adipofascial turnover forearm flap for a large defect in hand after squamous cell tumor extirpation. A case report. Orthop Res Traumatol Open J. 202I; 6(I): 8-II. doi: 10.17I40/ORTOJ-6-122

\begin{abstract}
| ABSTRACT |
Squamous cell carcinoma is a cancer that is rare in the hand. The extirpation of this cancer can leave an important cutaneous defect in many cases. The cutaneous covering at the back of the hand is a challenge for any surgeon, especially when there are large skin defects with exposure of tendons, bones or neurovascular structures. Here, we describe a clinical case where an adipofascial turnover forearm flap and full thickness skin graft were performed, after the extensive extirpation of the well-differentiated squamous cell carcinoma has been made.
\end{abstract}

Keywords

Flap; Adipofascial; Forearm; Hand; Skin defect; Carcinoma; Tumor; Squamous cell.

\section{INTRODUCTION}

$\mathrm{T}$ he skin carcinomas ${ }^{1}$ are a common cancer in the world; squamous cell carcinoma (SCC) is derived from the intermediate layer of the epidermis. The frequency is 2:1 men and women, which is very rare before 50 -years-old but more frequently around the 70 -years-old. ${ }^{2}$ This is an infiltrating tumor which can spread by contiguity, lymphatic system but in frequent by hematogenous route. ${ }^{3}$ SCC metastases are very rare in the hand, ${ }^{4}$ but predominant at the dorsal aspect of it. $^{5}$ For the treatment, various choices are available, depending on the tumor type, size, location and depth, as well as the age and overall health. The options include: excisional surgery, Mohs surgery, cryosurgery, electrosurgery, laser surgery, radiation, photodynamic therapy (PDT), topical medications.

The significant defect in the dorsal aspect of the hand is always a challenge for a surgeon, because it is very easy to have exposure of tendon, muscles, bones and neurovascular structures. There are several options for soft tissue coverage, some of them sacrifice a major artery; the most common of these arteries are based on the radial artery with or without skin. ${ }^{6}$ There are also soft tissue flaps which do not sacrifice major arteries, among them the posterior interosseous flap, dorsal ulnar flap or the adipofascial flap with skin graft. ${ }^{7-10}$ The last one is based on the vascular anatomy of the upper limb where there are vascular arches around the joints. There are perforators arteries which anastomose the posterior and the anterior interosseous arteries, and also others arteries from the subcutaneous adipose tissue, ${ }^{7,11,12}$ which provide blood supply to the dorsal fascia of the forearm. The advantages of this flap are less aesthetic problems and do not depend on a single vascular pedicle.

\section{CASE PRESENTATION}

A 64-year-old male, with a history of hypertension under treatment, was an active smoker for forty years, with no previous skin lesions. After a trauma with abrasion on the dorsum of the hand, he began to show the growth of an exophytic mass. The patient was unable to give any details about the matter. Two-months later, a biopsy was performed by a dermatologist, and the pathology report showed well-differentiated SCC, which is why he was referred to a hand surgery service. He was evaluated 10 -weeks after the onset of symptoms in conjunction with a medical oncologist, where an exophytic lesion with areas of necrosis on the surface was observed. The size of the exophytic lesion was approximately $3 \times 4 \mathrm{~cm}$ (Figure 1), with normal neurovascular examination, and 
no clinical observation of adherence in deep planes. An magnetic

Figure I. Squamous Cell Carcinoma at Dorsum of the Hand

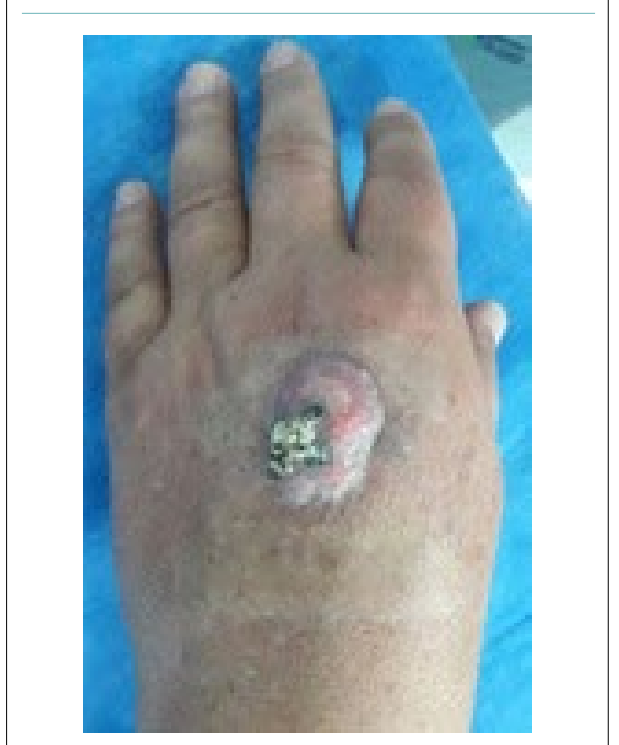

Figure 2. MRITI Axial Plane of the Hand

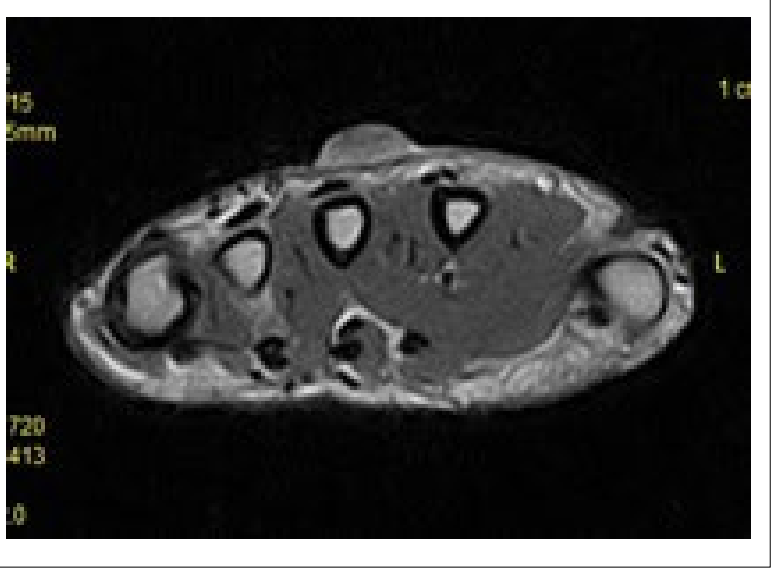

Figure 3. MRITI Sagital Plane of the Hand

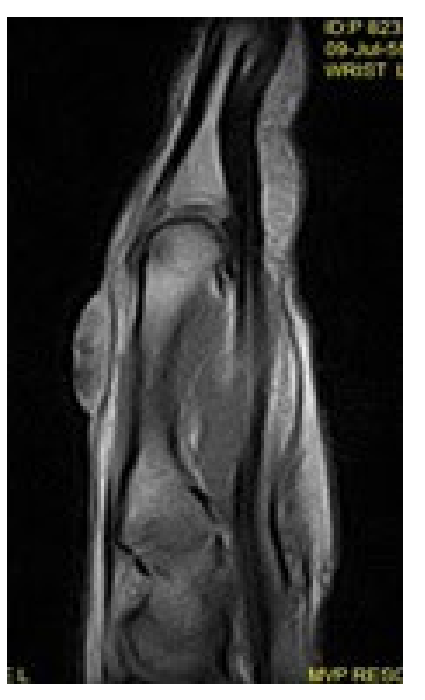

resonance imaging (MRI) study showed tumor growth in depth, without tendon involvement (Figures 2 and 3).

Under general anesthesia, a pneumatic tour niquet applied. A wide excision was made including skin, subcutaneous tissue and the tendon sheath of the extensor tendons which were under the SCC, leaving a skin defect of approximately $8 \times 7 \mathrm{~cm}$., with exposure of the common extensor tendons of the index, middle and ring fingers (Figure 4). A frozen biopsy was made and reported that $8 \mathrm{~mm}$ negative margin was obtained in all edges. A turnover adipofascial flap of the forearm was performed, in which an " $\mathrm{H}$ " incision is made on the dorsal side of the forearm (Figure 5), the dorsal skin is carefully lifted away from the adipofascial layer. The dorsal antebrachial fascia with adipose

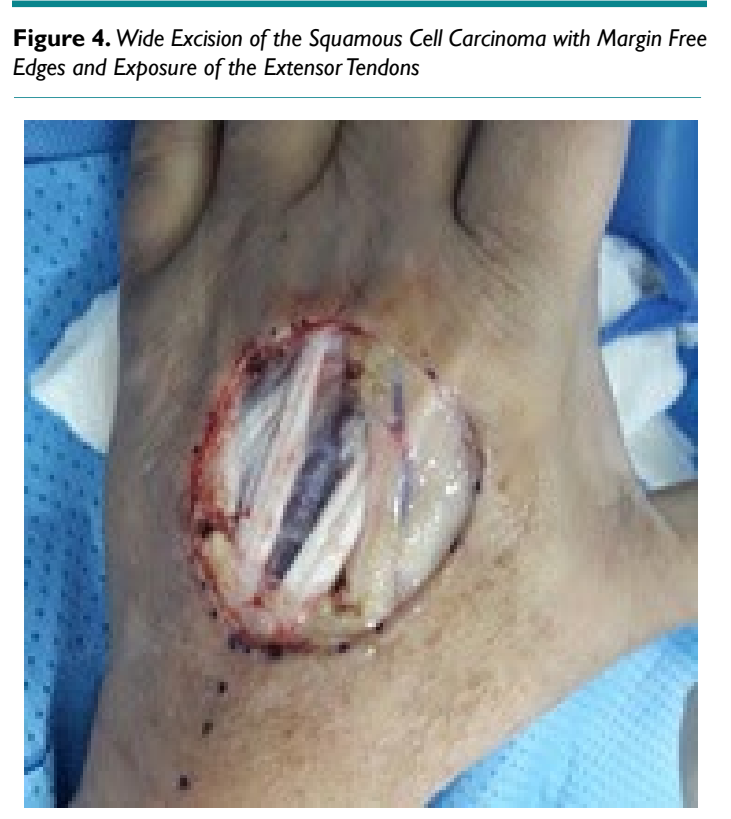

Figure 5. "H" Forearm Incision with Exposure of the Adipofascial Layer

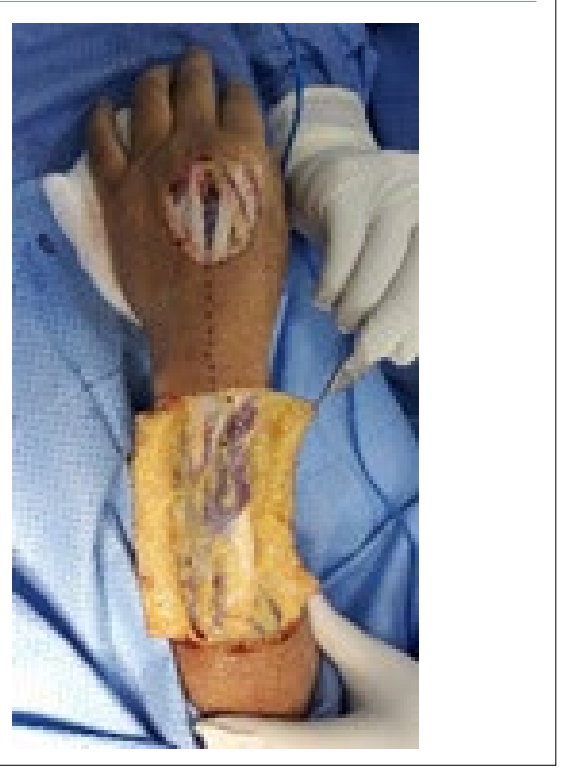


component was marked proximal after measuring the necessary length of the flap to cover the defect. To measure the length of the flap it is important to take into account the distance from the pivot point, which is around 4 to $6 \mathrm{~cm}$., proximal of the radial styloid to the distal edge of the defect; and also we have to add a few millimeters more in order not to have tension on the pedicle. The adipofascial flap was dissected free from the underlying paratenon or muscles from proximal to distal. The proximal arteries and veins were ligated and the perforators vessels were coagulated. The flap was passed through a skin tunnel in the dorsal wrist (Figure 6). After flap suture, it was covered with a full thickness skin graft (Figure 7); a Penrose drain was placed in the closure of the forearm, and finally immobilization was made with an antebrachial digital s-

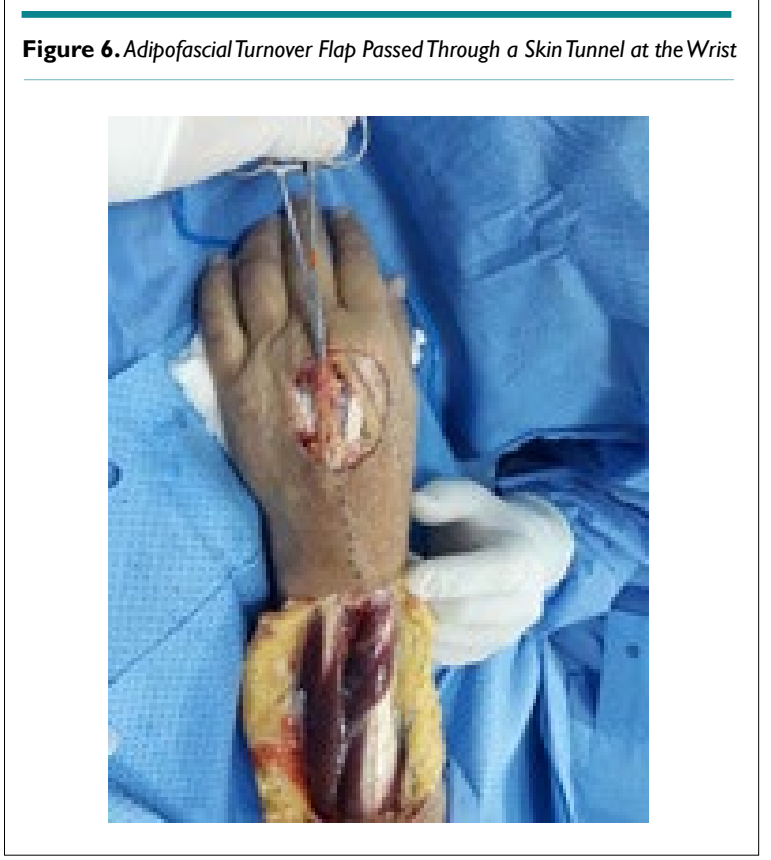

Figure 7. Adipofascial Turnover Flap Covered with a Full Thickness Skin Graft

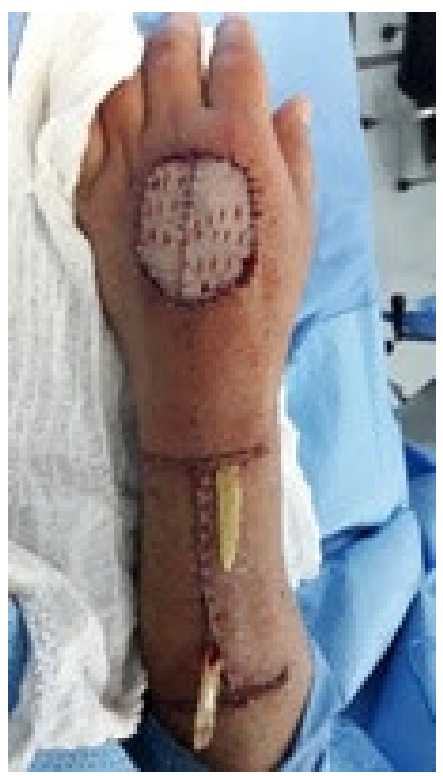

plint. The $\mathrm{d}$ rain was removed on the third post-operative day, the splint 14-days after, and physical therapy started the third week. Outpatient follow-up was performed every two-weeks, the skin graft had a partial necrosis which did not need any further procedure (Figures 8A and 8B). The patient showed a satisfactory post-operative outcome after two-months, with integration of the skin graft, and full motion of the fingers and wrist was recovered (Figure 9). The complete follow-up took one-year, when he was discharged from medical oncology service.

Figure 8. A) Post-operative Evolution at 10-days, B Partial Necrosis of Skin Graft at 5-weeks

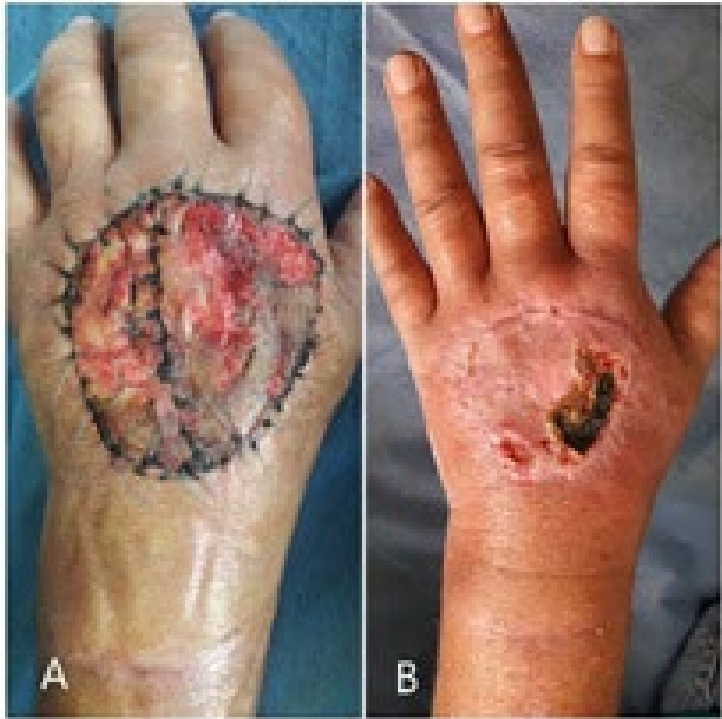

Figure 9. A) 8-weeks Post-operative with Finger Extension and Integration of the Skin Graft, B) Fingers Flexion

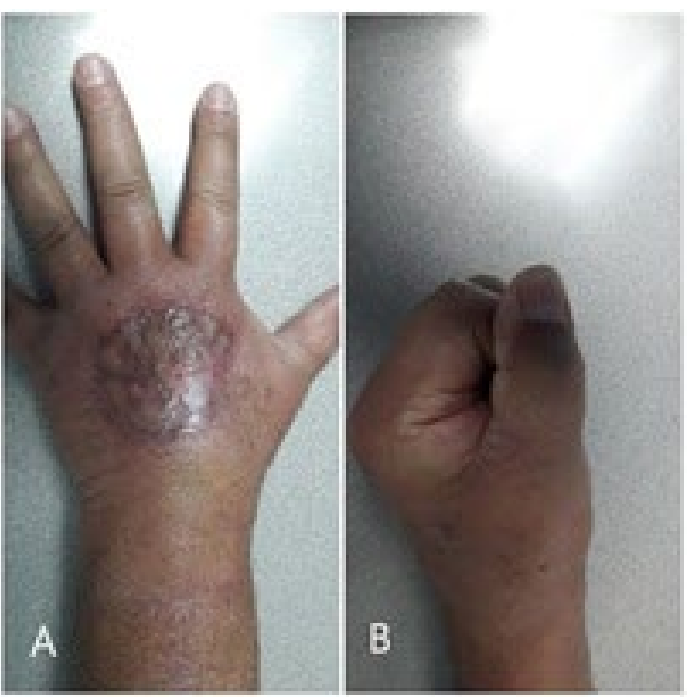

DISCUSSION

In this case, there has been a rapid growth of the SCC which is not very common because, generally, the growth is slower. That is 
why it was necessary to make a wide excision in order to extirpate the tumor, which left a large cutaneous defect, which could not be covered with local flaps.

When there is exposure of the bone or tendons without their sheath, we cannot place skin grafts directly because it compromises the tendon gliding, and/or the viability of the skin graft. ${ }^{13}$ In such cases, the options for the cutaneous coverage are used: regional, distant or free flaps. The majority of these procedures require prior microsurgical training. Most regional flaps are based on an axial pattern of vascularity of minor arteries. In older patients or smokers, when the vascular pedicle of the posterior interosseous or dorsal ulnar flap is rotated, it may present problems in blood supply. Other options are flaps based on major arteries, but sacrificing the radial or ulnar arteries. ${ }^{6,14}$ Lai et $\mathrm{al}^{15}$ in 1991, was the first one to describe adipofascial turnover flap based on the vascular arches around the joints, for the reconstruction of the skin defect in the dorsal aspect of the hand and finger, and is frequently used to cover the back of the fingers more than the back of the hand. ${ }^{16,17}$ In the forearm, the vascularity, not only depends on the anastomosis of the interosseous arteries, but also on the contribution of the dorsal arch of the wrist, reducing then the chances of necrosis. The skin graft can be performed at the same time of the adipofascial flap or in a second surgery.

In the literature, there are few cases of SCC at the back of the hand, but we did not find any article in which the coverage of the skin defect was performed with this adipofascial turnover flap after oncological extirpation of SCC.

This flap is reliable, straightforward, and allows a good coverage surface, with good cosmetic result. It can be used safely to cover the complex wounds with exposed tendon, bone, or neurovascular structures, and since it does not require microsurgical training, this is a flap that can be performed by Orthopedics or Hand Surgeons without experience in microsurgery, for traumatic and non-traumatic reconstruction.

\section{CONSENT}

The written and verbal consent of the patient could not be obtained to reproduce the information and photographs that appear in this article despite multiple attempts to contact him. The author confirms that the submitted article is not being considered or previously published.

\section{REFERENCES}

1. Gallego C, Puig A. Carcinoma espinocelular en cuero cabelludo. [Spanish]. Rev Esp Sanid Penit. 2014; 16: 24-25.

2. Felicitas MT, Melkys C. Carcinoma de Células Escamosas. A Propósito de un Caso. [Spanish]. Rev Int Cienc Podol. 2014; 8(1): $37-44$.

3. Muñoz Pérez MA, Escudero J, Camacho F, Rojo J, Vera I. Carcinoma espinocelular agresivo con presentación atípica. Ac- tas Dermo-Sifiliográficas. 2001; 92: 39-45. doi: 10.1016/S00017310(01)79139-9

4. Kim TH, Lee J, Park L, Park JU, Tack Kwon S. Basaloid squamous cell carcinoma on the skin of the hand. Arch Plast Surg. 2015; 42(6): 808-810. doi: 10.5999/aps.2015.42.6.808

5. Uwe W, Sven T, Wolfgang A, Gesina H, Birgit H. Advanced ulcerated squamous cell carcinoma of the hand with locoregional axillary lymph node metastasis-case report and literature review. Maced J Med. 2019; 7(5): 791-93. doi: 10.3889/oamjms.2019.200

6. Akdağ O, Yıldıran G, Sütçü M, Karameşe M. Posterior interosseous flap versus reverse adipofascial radial forearm flap for soft tissue reconstruction of dorsal hand defects. Ulus Travma Acil Cerrabi Derg. 2018; 24(1): 43-48. doi: 10.5505/tjtes.2017.41196

7. Yii NW, Niranjan NS. Fascial flaps based on perforators for reconstruction of defects in the distal forearm. Br J Plastic Surg. 1999; 52: 534-540. doi: 10.1054/bjps.1999.3170

8. Silva JB, Padoin AV, Gazzalle A, da Cunha GL. Dorsal forearm adipofascial turnover flap among the elderly. J Hand Surg Eur Vol. 2011; 36(5): 370-375. doi: 10.1177/1753193411399995

9. Deal N, Barnwell J, Li Z. Soft-tissue coverage of complex dorsal hand and finger defects using the turnover adipofascial flap. $J$ Reconstr Microsurg. 2011; 27: 133-138. doi: 10.1055/s-0030-1268852

10. Sungur N, Özdemir R, Gürhan M, Sensöz Ö, Kilinç H, Ortak T. Adipofascial turn-over flap for the reconstruction of complicated soft tissue defects of distal forearm and hand. Tech Hand Up Extrem Surg. 2001; 5(2): 72-77. doi: 10.1097/00130911-20010600000002

11. Kim KS. Distally based dorsal forearm fasciosubcutaneous flap. Plast Reconstr Surg. 2004; 114(2): 389-396. doi: 10.1097/01. prs.0000131985.32954.c0

12. Medalie DA. Perforator-based forearm and hand adipofascial flaps for the coverage of difficult dorsal hand wounds. Ann Plast Surg. 2002; 48: 477-483. doi: 10.1097/00000637-200205000-00005

13. Almobarak BA, Mohamed ME, Hassan MI. Different modalities of soft tissue coverage of hand and wrist defects. Clin Pract. 2018; 15(1): 466-472.

14. Weichman K, Allen RJ, Thanik V, Matros E, Mehrara BJ. Adipofascial anterolateral thigh free flaps for oncologic hand and foot reconstruction. Reconstr Microsurg. 2015; 31(9): 684-687. doi: $10.1055 / \mathrm{s}-0035-1558431$

15. Lai CS, Lin SD, Yang CC, Chou CK. The adipofascial turnover flap for complicated dorsal skin defects of the hand and finger. $\mathrm{Br}$ J Plast Surg. 1991; 44: 165-169. doi: 10.1016/0007-1226(91)90119-5

16. Camporro D, Vidal D, Robla D. Extended applications of 
distally based axial adipofascial flaps for hand and digits defects. J Plast Reconstr Aesthet Surg. 2010; 63: 2117-2122. doi: 10.1016/j. bjps.2009.11.020
17. Chung Y-K, Choi J-H, Kim J, Chung S. Refinements of adipofascial flap for small defects of fingers and toes: Indication and surgical tips. Arch Reconstr Microsurg. 2016; 25(2): 25-28. doi: 10.15596/ARMS.2016.25.2.25 